\title{
Rural Workers Would Benefit from Unemployment Insurance Modernization
}

$\mathrm{I}$ $\mathrm{n}$ many states, when part-time workers lose their jobs, they are not eligible for unemployment insurance (UI) benefits even though their employers pay both federal and state unemployment taxes on their wages. That may soon change, because under the new economic stimulus plan, states now have an opportunity to modernize their UI programs so that part-time workers who lose their jobs through no fault of their own can claim UI benefits. Rural workers and their families would benefit from updating UI to include part-time workers because rural workers are more likely to work part-time and because many states that do not now provide UI benefits to part-time workers have higher-than-average proportions of rural residents.

\section{Background}

Unemployment insurance in the United States is provided through a federal-state program enacted during the Great Depression, a time when the typical worker was a full-time male breadwinner in a single-earner family. The labor force looks very different today, however. Women have entered the labor force in large numbers, and a large proportion of workers, especially women, hold part-time jobs that provide income critical to their families' well-being. Twenty-seven percent of women and 13 percent of men in the labor force today work part-time. State unemployment eligibility criteria have not kept pace with these changes, and a high percentage of all workers are unable to claim benefits when they lose a job. In 2008, only 37 percent of unemployed workers received regular state unemployment insurance benefits. ${ }^{1}$ Nearly two-thirds of unemployed workers were not eligible.

\section{Part-time Workers and Unemployment Insurance}

Although one in five U.S. workers is employed part-time, only about half of states allow part-time workers to claim benefits. ${ }^{2}$ With the national unemployment rate now at 8.5 percent $^{3}$ and almost certain to go higher, the safety net of unemployment insurance is more critical to American workers than at any time in the last quarter century. Excluding part-time workers means that families who rely on earnings from part-time jobs have no safety net when they lose those jobs.

\section{An Opportunity for States}

Fortunately, states now have the opportunity to obtain federal assistance to include part-time workers in their UI programs. The American Recovery and Reinvestment Act of 2009 (ARRA) seeks to improve unemployment insurance in both temporary and permanent ways so that unemployed workers have a stronger safety net in difficult times. In response to the current recession, the ARRA provides funds to states for temporary extensions and increases in benefits and temporary subsidies for laid-off workers' COBRA health insurance premiums. In addition, the ARRA offers states the opportunity to receive federal incentive funding to make permanent modernizations to their UI programs so that more workers who lose jobs can collect benefits, including part-time workers. The ARRA contains a total of $\$ 7$ billion in modernization funding that may be claimed by states.

To receive unemployment modernization incentive funding, states must make specific changes to their UI programs. The first one-third of a state's allotted federal incentive funding could be claimed if a state adopts an "alternative base period" (ABP), for determining eligibility for benefits. In order to qualify for benefits, workers must have a minimum amount of earnings, set by each state, during a certain calendar base period. Most states still use an outdated base period that excludes workers' earnings in the most recent quarter. Often, however, workers who do not qualify for benefits using the traditional base period would become eligible if their most recent earnings could be considered. ${ }^{4}$ This is especially true of low-wage workers 
who are frequently ineligible because of insufficient earnings. ${ }^{5}$ Including more recent earnings in benefits eligibility calculations would thus expand coverage to more workers, especially those in low wage jobs. ${ }^{6}$

The remaining two-thirds of a state's UI modernization incentive funding could be claimed if the state adopted at least two of four other possible modernizations to its program. ${ }^{7}$ One of the four modernization options open to states is to extend UI coverage to workers who are seeking part-time work. ${ }^{8}$ At present only 22 states and the District of Columbia provide part-time coverage that complies with UI modernization requirements (see Figure 1). Another three states cover part-time workers, but their laws need modification in order to qualify for incentive funding. The remaining 25 states have no part-time worker coverage at all. In 2008, 20 percent of U.S. workers worked part-time. ${ }^{9}$ This means that that in those 25 states without coverage, there are large numbers of workers who have no safety net to rely on when they lose a part-time job. Women are more likely to work part-time than men, so they are at greater risk of being unable to collect UI benefits when they lose their jobs. Twenty seven percent of all employed women work part-time, compared with 13 percent of employed men.

\section{Figure 1. PART-TIME WORKER UNEMPLOYMENT INSURANCE COVERAGE AND RURAL POPULATION} PERCENTAGE BY STATE

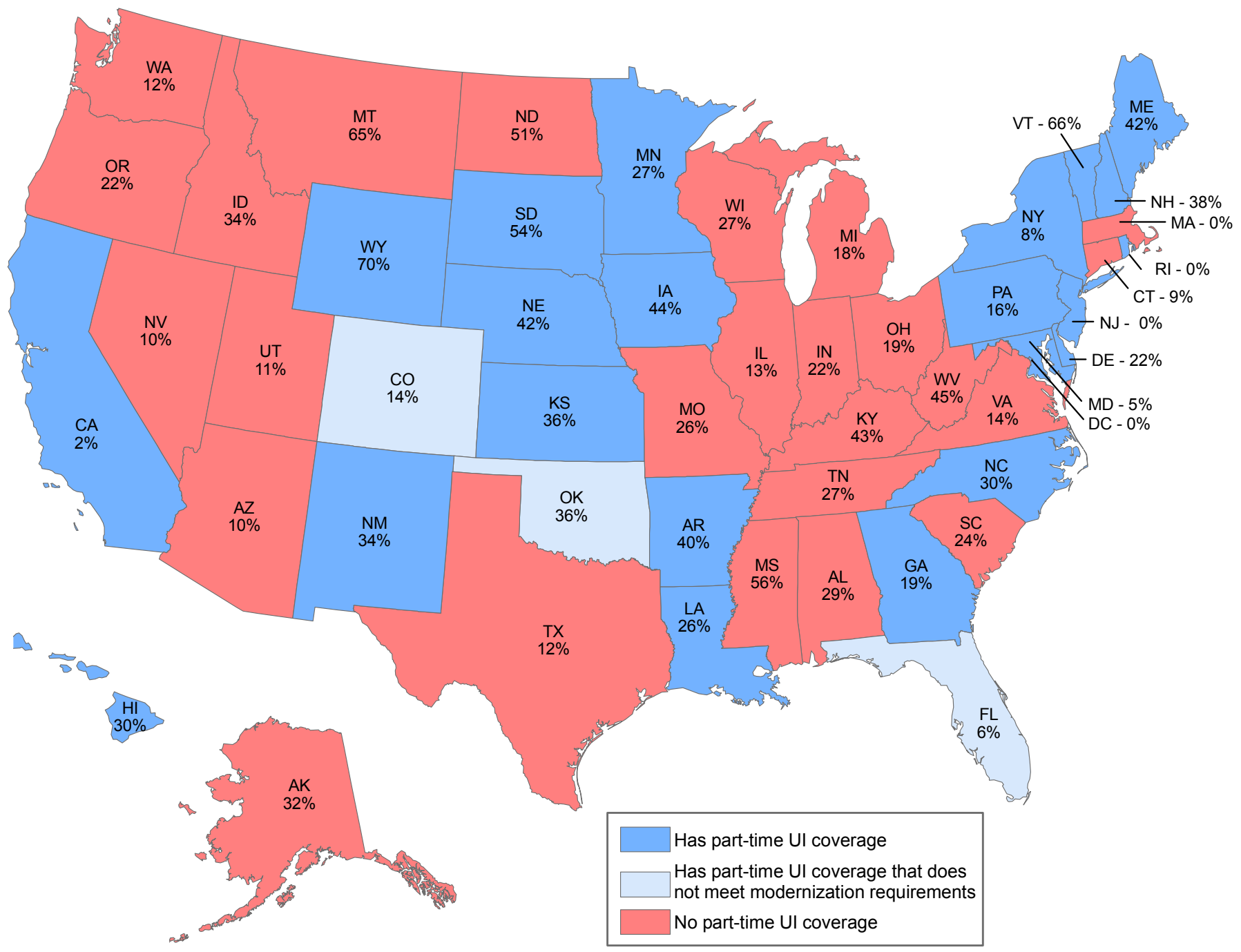

Note: State UI program information is accurate as of April 24, 2009.

Sources: National Employment Law Project; US Census Bureau 2008 County Population Estimates. 


\section{Rural Families Need Part-time Worker UI Coverage}

Rural workers would benefit substantially from part-time worker coverage. Rural workers are slightly but significantly more likely than others to be part-timers. Twenty-one percent of all rural workers hold part-time jobs, compared with 20 percent of suburban workers and 18 percent of central city workers. Rural workers in the Northeast (23 percent) and the West (25 percent) are especially likely to be working part-time when compared with central city dwellers (16 percent in the Northeast and 19 percent in the West) (see Table 1). Although rates of part-time work in the South are somewhat lower than in other regions, many Southern states have high levels of poverty and large percentages of rural residents. Their working rural residents need a stronger safety net.

TABle 1. PERCENT OF WORKERS Who ARE EMPlOYED PART-TIME

$\begin{array}{lccccc} & \text { Nationwide } & \text { Northeast } & \text { Midwest } & \text { South } & \text { West } \\ \text { All workers } & 20 & 20 & 22 & 17 & 21 \\ \text { Rural } & 21 & 23 & 24 & 17 & 25 \\ \text { Suburban } & 20 & 20 & 22 & 17 & 22 \\ \text { Central City } & 18 & 16 & 21 & 16 & 19\end{array}$

Figure 1 shows that the states that already provide parttime worker coverage are clustered in the Northeast and the Midwest, while the states where workers lack this important safety net are concentrated in the West, the South, and in eastern portions of the Midwest. Many of the states without part-time coverage are heavily rural. Twenty-six states have one-quarter or more of their populations residing in rural areas, and 11 of these offer no part-time worker coverage (Alabama, Alaska, Idaho, Kentucky, Mississippi, Missouri, Montana, North Dakota, Tennessee, West Virginia, and Wisconsin) (see Figure 1 and Table 2). ${ }^{10}$ In these states, modernizing UI programs to include part-time workers would be especially beneficial to rural workers and their families. Seven states already cover part-time workers but do not have an ABP in effect, and four of these six states (Kansas, Louisiana, Nebraska, and Wyoming) have more than one-quarter of their populations living in rural areas (see Table 2). These states would have to put an ABP in effect before being able to qualify for modernization incentive funding. Once they did so, however, federal incentive funds would be used to cover the costs of their existing UI programs. Two heavily rural states, Iowa and South Dakota, recently enacted legislation enabling them to claim UI modernization funding. ${ }^{11}$

Source: December 2008 Current Population Survey

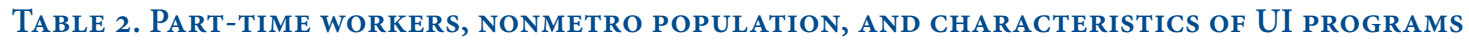

\begin{tabular}{|c|c|c|c|c|c|c|c|}
\hline $\begin{array}{l}\text { Percer } \\
\text { who w } \\
\text { Dece }\end{array}$ & $\begin{array}{l}\text { ent of workers } \\
\text { Nere part-time } \\
\text { ember } 2008^{1}\end{array}$ & $\begin{array}{l}\text { Estimated total number } \\
\text { of part-time workers } \\
\text { December } 2008^{1}\end{array}$ & $\begin{array}{c}\text { Margin of error } \\
\text { for number of } \\
\text { part-time workers }\end{array}$ & $\begin{array}{l}\text { Nonmetro as } \\
\% \text { of total } \\
\text { Population }\end{array}$ & $\begin{array}{l}\text { Has ABP } \\
\text { in place? }\end{array}$ & $\begin{array}{l}\text { Has qualifying } \\
\text { part-time } \\
\text { Ul benefits? }\end{array}$ & $\begin{array}{c}\text { UI } \\
\text { recipiency } \\
\text { rate (\%) }\end{array}$ \\
\hline United States & 20 & $28,294,434$ & $\pm 88,069$ & 16 & $\mathrm{~N} / \mathrm{A}$ & $\mathrm{N} / \mathrm{A}$ & 37 \\
\hline Alabama & 17 & 344,765 & 10,178 & 29 & No & No & 35 \\
\hline Alaska & 22 & 73,924 & 2,043 & 32 & No & No & 47 \\
\hline Arizona & 20 & 595,164 & 17,115 & 10 & No & No & 28 \\
\hline Arkansas & 18 & 216,051 & 6,487 & 40 & Yes & Yes & 50 \\
\hline California & 21 & $3,645,365$ & 41,167 & 2 & Yes & Yes & 38 \\
\hline Colorado & 19 & 489,881 & 9,849 & 14 & No & $\mathrm{No}^{4}$ & 23 \\
\hline Connecticut & 21 & 375,354 & 7,942 & 9 & Yes & No & 45 \\
\hline Delaware & 19 & 79,741 & 2,012 & 22 & No & Yes & 49 \\
\hline District of Columbia & 12 & 37,347 & 822 & 0 & Yes & Yes & 23 \\
\hline Florida & 18 & $1,540,650$ & 24,532 & 6 & No & $\mathrm{No}^{4}$ & 31 \\
\hline Georgia & 20 & 907,388 & 20,201 & 19 & Yes & Yes & 28 \\
\hline Hawaii & 21 & 123,549 & 3,189 & 30 & Yes & Yes & 46 \\
\hline Idaho & 22 & 149,753 & 4,691 & 34 & No & No & 53 \\
\hline Illinois & 20 & $1,229,546$ & 21,897 & 13 & Yes & No & 37 \\
\hline
\end{tabular}




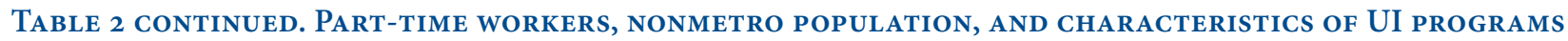

\begin{tabular}{|c|c|c|c|c|c|c|c|}
\hline State & $\begin{array}{l}\text { Percent of workers } \\
\text { who were part-time } \\
\text { December } 2008^{1}\end{array}$ & $\begin{array}{l}\text { Estimated total number } \\
\text { of part-time workers } \\
\text { December 2008' }\end{array}$ & $\begin{array}{c}\text { Margin of error } \\
\text { for number of } \\
\text { part-time workers }\end{array}$ & $\begin{array}{l}\text { Nonmetro as } \\
\% \text { of total } \\
\text { Population }\end{array}$ & $\begin{array}{l}\text { Has ABP } \\
\text { in place? }\end{array}$ & $\begin{array}{l}\text { Has qualifying } \\
\text { part-time } \\
\text { UI benefits? }\end{array}$ & $\begin{array}{l}\text { UI } \\
\text { recipiency } \\
\text { rate (\%) }\end{array}$ \\
\hline Indiana & 20 & 575,129 & 14,419 & 22 & No & No & 39 \\
\hline lowa & 23 & 355,138 & 8,052 & 44 & Yes & Yes & 43 \\
\hline Kansas & 22 & 322,296 & 8,380 & 36 & No & Yes & 34 \\
\hline Kentucky & 19 & 351,309 & 9,081 & 43 & No & No & 31 \\
\hline Louisiana & 13 & 243,826 & 6,730 & 26 & No & Yes & 28 \\
\hline Maine & 24 & 156,254 & 3,823 & 42 & Yes & Yes & 33 \\
\hline Maryland & 16 & 449,677 & 8,094 & 5 & No & Yes & 39 \\
\hline Massachusetts & 23 & 706,762 & 19,015 & 0 & Yes & No & 54 \\
\hline Michigan & 26 & $1,153,950$ & 26,577 & 18 & Yes & No & 40 \\
\hline Minnesota & 25 & 688,761 & 14,067 & 27 & Partial & Yes & 38 \\
\hline Mississippi & 15 & 183,875 & 5,699 & 56 & No & No & 28 \\
\hline Missouri & 17 & 465,467 & 10,562 & 26 & No & No & 33 \\
\hline Montana & 25 & 119,927 & 4,160 & 65 & No & No & 44 \\
\hline Nebraska & 23 & 219,986 & 5,450 & 42 & No & Yes & 33 \\
\hline Nevada & 14 & 179,722 & 4,099 & 10 & No & No & 44 \\
\hline New Hampshire & 21 & 152,153 & 3,157 & 38 & Yes & Yes & 36 \\
\hline New Jersey & 18 & 780,906 & 15,608 & 0 & Yes & Yes & 55 \\
\hline New Mexico & 22 & 207,375 & 7,087 & 34 & Yes & Yes & 36 \\
\hline New York & 18 & $1,611,415$ & 23,949 & 8 & Yes & Yes & 40 \\
\hline North Carolina & 19 & 756,910 & 17,070 & 30 & Yes & Yes & 38 \\
\hline North Dakota & 22 & 77,816 & 2,091 & 51 & No & No & 32 \\
\hline Ohio & 24 & $1,320,567$ & 26,172 & 19 & Yes & No & 33 \\
\hline Oklahoma & 17 & 278,870 & 7,711 & 36 & Partial & $\mathrm{No}^{4}$ & 26 \\
\hline Oregon & 27 & 494,954 & 14,615 & 22 & No & No & 50 \\
\hline Pennsylvania & 20 & $1,222,601$ & 21,848 & 16 & No & Yes & 57 \\
\hline Rhode Island & 24 & 123,318 & 3,141 & 0 & Yes & Yes & 36 \\
\hline South Carolina & 20 & 375,905 & 10,571 & 24 & No & No & 36 \\
\hline South Dakota & 20 & 86,088 & 2,121 & 54 & Yes & Yes & 18 \\
\hline Tennessee & 18 & 507,711 & 13,863 & 27 & No & No & 28 \\
\hline Texas & 15 & $1,708,927$ & 21,734 & 12 & No & No & 21 \\
\hline Utah & 21 & 272,038 & 7,689 & 11 & No & No & 32 \\
\hline Vermont & 23 & 76,928 & 1,933 & 66 & Yes & Yes & 47 \\
\hline Virginia & 17 & 670,872 & 13,305 & 14 & Yes & No & 27 \\
\hline Washington & 23 & 752,995 & 18,962 & 12 & Yes & No & 37 \\
\hline West Virginia & 14 & 104,866 & 2,812 & 45 & No & No & 44 \\
\hline Wisconsin & 23 & 673,570 & 15,276 & 27 & Yes & No & 60 \\
\hline Wyoming & 20 & 57,092 & 1,457 & 70 & No & Yes & 33 \\
\hline
\end{tabular}

Source: December 2008 Current Population Survey; U.S. Census Bureau; National Employmment Law Project; US Department of Labor

\footnotetext{
${ }^{1}$ The Census Bureau recommends using three-year averages when using CPS data to make comparisons across states. However, in order to present more timely data in a rapidly changing economic climate, the number and percent of part-time workers were estimated using only the more recent December 2008 CPS data. State-to-state comparisons should thus be made with caution since margins of error are larger when only one month of data is used.
}

${ }^{2}$ Margin of error is based on a 95 percent confidence interval.
${ }^{3}$ The nonmetro percentages were estimated using 2008 U.S. Census Bureau county population estimates and USDA Economic Research Service county typology codes.

${ }^{4}$ Colorado, Florida, and Oklahoma provide UI benefits to part-time workers; however their laws do not meet incentive funding requirements, and legislation is needed to qualify.

${ }^{5}$ State information on $\mathrm{ABP}$ and part-time coverage is accurate as of April 24, 2009. 
In addition, in several states without part-time worker coverage (Arizona, Kentucky, Mississippi, North Dakota, Tennessee, Texas, Utah, and Virginia), the UI recipiency rate-the percent of unemployed who are covered by the program-is 5 percentage points or more below the already low U.S. average of 37 percent. Extending benefits to parttime workers in these states would increase the percentage of the unemployed who can collect benefits when they are out of work through no fault of their own.

Table 2 also shows the approximate number of part-time workers in each state estimated from December 2008 Current Population Survey data. The total estimated number of part-time workers in the 25 states that have no part-time unemployment insurance benefits is just over 13 million. Although the Current Population Survey design does not permit a state-by-state estimate of the number of rural part-time workers, applying the national percentage of nonmetropolitan area residents of 16 percent to the total number of part-time workers in the states without part-time unemployment insurance benefits suggests that there could be more than 2 million rural part-time workers residing in states without this important benefit.

\section{Conclusion}

The federal-state unemployment insurance system was conceived and implemented during the Great Depression to provide a safety net to workers who have become unemployed through no fault of their own. The characteristics of the U.S. labor force have changed substantially since then, and only 37 percent of unemployed workers are now able to claim regular state UI benefits. Part-time workers comprise a major segment of the labor force-approximately 20 percent of workers - that receives no unemployment insurance protection in many states despite the fact that employers pay both state and federal unemployment taxes on the wages of part-time workers. The UI modernization provisions of the ARRA offer states a unique opportunity to update their UI systems so that more workers who lose jobs, including part-time workers, will have income to fall back on while they search for work. The rapid pace of job loss and high rate of unemployment in the U.S. during the current recession make this a particularly important time for states to institute UI reforms.

The intent of the UI modernization provisions of the ARRA is to enable states to make permanent changes to their UI systems, and federal incentive funding would cover the cost of these changes temporarily. Some state leaders have expressed concern that modernization would create permanent burdens that would require tax increases on employers in the future; ${ }^{12}$ however, such concern is misplaced. States who enact UI modernizations now would be free to change their laws in the future, but it is likely that the benefits of a stronger safety net for workers will outweigh the costs. The federal funds flowing into states would help the growing ranks of unemployed workers make ends meet while also stimulating sagging state economies.

Rural workers and their families stand to benefit from states' adoption of part-time worker UI coverage since rural workers are slightly more likely to hold part-time jobs than their suburban or central city counterparts. In addition, a number of states that currently exclude part-time workers have higher-than-average percentages of rural residents, leaving many rural Americans unprotected by a crucial economic safety net.

\section{Data Used}

This fact sheet uses data from the December 2008 Current Population Survey. Comparisons discussed in the text are significant at the .05 level.

\section{Endnotes}

${ }^{1}$ U.S. Department of Labor. Employment \& Training Administration. Unemployment Insurance Chartbooks. "Regular Program Insured Unemployment as a Percent of Total Unemployment." http://www.doleta.gov/unemploy/ chartbook/chartrpt.cfm, accessed March 15, 2009.

${ }^{2}$ National Employment Law Project. “The Unemployment Insurance Modernization Act: Filling the Gaps in the Unemployment Safety Net While Stimulating the Economy." February 17, 2009. http://www.nelp.org/page/-/UI/uima. fact.sheet.jan.09.pdf?nocdn=1, accessed March 1, 2009.

${ }^{3}$ U.S. Bureau of Labor Statistics. National unemployment rate for March 2009. http://www.bls.gov, accessed April 20, 2009.

${ }^{4}$ Stone, Chad, Robert Greenstein, and Martha Coven. 2007. "Addressing Longstanding Gaps in Unemployment Insurance Coverage." Washington, DC: Center for Budget and Policy Priorities.

${ }^{5}$ National Employment Law Project. "Implementing the Model Provisions of the Unemployment Insurance Modernization Act in the States." February 17, 2009. http:// nelp.3cdn.net/dcc61269e71d7220ef_t8m6bpprp.pdf, accessed April 24, 2009.

${ }^{6}$ Ibid.

${ }^{7}$ To qualify for the second two-thirds of modernization incentive funding, states must extend benefits to at least two of the following four groups: (1) workers seeking part-time work; (2) workers who leave their jobs for compelling family reasons of either illness or disability, domestic violence, or spousal relocation; (3) workers who qualify for benefits but 
need additional benefit amounts to care for dependents; or (4) workers who have been permanently laid off and need extra benefits while they participate in job training. Source: National Employment Law Project, February 17, 2009.

${ }^{8}$ Under the part-time modernization requirement, a state must not deny unemployment benefits to an individual solely because that individual is seeking only part-time work. States are permitted but not required to include one exception: states may deny benefits to an individual who is seeking part-time work but who did not work part-time during the majority of weeks in his or her base period. Source: U.S. Department of Labor. http://wdr.doleta.gov/directives/ attach/UIPL/UIPL14-09c.pdf, accessed April 20, 2009.

${ }^{9}$ In this report, for the purposes of determining the percentage of workers who are part-time, I have defined part-time work as less than 35 hours per week. Under the unemployment modernization provisions of the ARRA, states that provide UI coverage to part-time workers may define "seeking part-time work" in one of three ways: (1) an individual who is "willing to work at least 20 hours per week;" (2) an individual who "is available for a number of hours per week comparable to the individual's part-time work experience in the base period"; or (3) "an individual who is available for hours that are comparable to the individual's work at the most recent separation from employment." Source: U.S. Department of Labor. http://wdr.doleta. gov/directives/attach/UIPL/UIPL14-09c.pdf, accessed April 20, 2009.

${ }^{10}$ Legislation for part-time coverage has been introduced in Idaho and Alabama. Source: National Employment Law Project. "States Modernize and Expand Unemployment Insurance Under the American Recovery and Reinvestment Act." April 15, 2009. http://nelp.3cdn.net/d53aa4c20cb226240b_sgm6b91p3.pdf, accessed April 24, 2009

${ }^{11}$ National Employment Law Project. “Iowa \& South Dakota the First States to Approve Unemployment Insurance Stimulus Funds.” March 13, 2009. http://www.nelp.org/ page/-/UI/iowa.south.dakota.press.release.pdf?nocdn=1, accessed April 10, 2009.

${ }^{12}$ Luo, Michael. "Jobless Angry at Possibility of No Benefits.” New York Times. February 27, 2009.

\section{A B OUT THE AUTHOR}

Anne Shattuck is a Ph.D. student in sociology and a research assistant at the Carsey Institute. (anne.shattuck@ unh.edu)

\section{A C K N OW L E D G M E N T S}

The author wishes to thank Christine Riordan of the National Employment Law Project; Debbie Stein of the Hatcher Group; and Mil Duncan, Marybeth Mattingly, and Kristin Smith of the Carsey Institute for their comments and assistance in the preparation of this fact sheet.

\section{$\triangle$ UNIVERSITY Ail of NEW HAMPSHIRE}

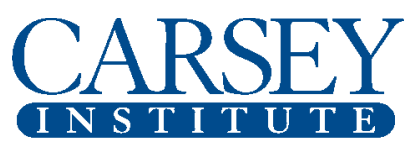

Building knowledge for families and communities

The Carsey Institute conducts policy research on vulnerable children, youth, and families and on sustainable community development. We give policy makers and practitioners timely, independent resources to effect change in their communities.

The Carsey Institute is supported by the Annie E. Casey Foundation's initiative to strengthen rural families and by the W.K. Kellogg Foundation.

Huddleston Hall

73 Main Street

Durham, NH 03824

(603) 862-2821

www.carseyinstitute.unh.edu 